


\title{
How Parents' skills affect their time-use with children: Evidence from an RCT experiment in Italy ${ }^{1}$
}

\author{
Daniela Del Boca (University of Turin and CCA), Chiara Daniela Pronzato (University of Turin \\ and CCA), Lucia Schiavon (University of Turin and CHILD)
}

Nov $9^{\text {th }}, 2020$

\begin{abstract}
This paper investigates the impact of parenting courses on fragile families' time use with their children. Courses aimed at raising parental awareness of the importance of educational activities are offered in four Italian cities (Naples, Reggio Emilia, Teramo and Palermo) within the framework of the social program "FA.C.E. Farsi Comunità Educanti" and with the cooperation of the program "Con i Bambini" 2 . To conduct the impact evaluation ${ }^{3}$, we designed a randomized controlled trial involving random assignment of the families (mostly mothers). At the end of the intervention, we administered an assessment questionnaire both to the treatment group, which took the course, and to the control group, which did not. Comparing the outcomes, we find attending the course increased families' awareness of the importance of educational activities for children, the frequency with which they read to the child, and their desire to spend more time with the child.
\end{abstract}

J.E.L: J13, D1, I26

Key words: parenting, use of time, randomized controlled trial

\footnotetext{
${ }^{1}$ We thank Chiara Baldelli and the rest of FA.C.E.'s team of Reggio Children Foundation for their support. We also thank Paola Battaglia for research assistance.

${ }^{2}$ Con i Bambini is a non-profit organization whose mission is to implement programs contrasting the educational poverty of children, funded by a Memorandum of Intent (Protocollo d'Intesa) signed between the Italian Ministry of Labor and the Association of Italian Banking Foundations.

${ }^{3}$ Evaluation of FA.C.E. was carried out at the Impact Evaluation Institute (IEU) at Collegio Carlo Alberto, whose technical support is gratefully acknowledged.
} 


\section{Introduction and background}

Supporting the development of parental skills and awareness has increasingly been on the agenda of policy makers in Europe since the 1990s (European Union 2013). Outreach to families is typically delivered through early childhood and family information centers that offer a wide range of community health and social services. Most programs include parenting courses designed for families with preschoolers, as interventions targeting this age group have proven the most costeffective and efficient (Daly 2007, Moran et al. 2004). Several recent programs to increase parental awareness of the importance of parenting skills have been directed towards fragile families. Research evaluating these programs show that they have raised parental awareness, parenting skills and children's cognitive and socioemotional outcomes (Doyle et al. 2017, Doyle 2020, Wagner and Clayton 1999, Daly et al. 2014).

These programs are also backed up by a large body of literature known as the economics of skills formation, which analyzes the effect of parents' behavior on children's well-being. Several surveys have shown that parental time investments in their children have a powerful influence on child cognitive and non-cognitive outcomes, and that they are the most important input in the child development process (Carneiro and Heckman 2003, Del Boca 2015), outweighing the influence of non-parental time investments.

These studies have also compared the impact of mothers' and fathers' time with children. While the mother's time is widely recognized as a crucial input for a child's cognitive development, the father's time has been found to be equally productive, especially at some stages of a child's life. In recent decades, the amount of time fathers spend with their children has increased markedly, partly offsetting the decline in mothers' time. A study using time-use data finds that inputs provided by both parents are important for children's cognitive development, with impacts differing according to whether the parents are actively engaged with or merely passively present when spending time with the child. Active time is more "productive" than passive time (Del Boca et al 2014). Other studies confirm these results. Hsin (2009) defines different measures of maternal total time, engaged time and quality time, finding a positive and persistent effect of the total time spent by mothers with their children, but an even greater effect of time spent playing with them.

Recent studies have looked at different types of parental time activities (educational and noneducational), showing that the latter are the most important determinants of childhood development (Del Boca et al., 2017; Fiorini and Keane, 2014).

Inputs in the cognitive production function have a different effect at different stages of a child's life. The family's contribution to child development diminishes as the child grows older, suggesting that there is less room for policy interventions in late childhood and adolescence (Del Boca et al 2017). The early years represent an important phase for children's development, in which the returns of parental investments are larger (Heckman 2000, Guryan et al 2008, Campbell et al 2014). A recent area of research has also considered parenting style - such as how warm, strict, or communicative a parent is - as an important determinant of a child's skills (Doepke and Zilibotti, 2017). 
Building on some of the main findings of this literature, we set out to analyze the impact of parental awareness of the importance of engaging in educational activities with children aged 0-6. We study the impact of a parenting course on parents' and children's time use by designing a randomized controlled trial: families were randomly invited to participate in the project, and the outcomes of those who attended the course were compared with those who did not. Our findings show that course attendance the participants' awareness of the importance of educational activities for children, the frequency with which they read to the child, and their desire to spend more time with the child.

\section{The intervention and course description}

“FA.C.E. Farsi Comunità Educanti” ("Becoming Educating Communities”) is a social program promoted by the institution "Con i Bambini" 4 and implemented in four Italian cities: Napoli, Palermo, Reggio Emilia and Teramo. The aim of the program is to increase access to educational and care services for children aged $0-6$ by promoting family engagement, particularly among the socially vulnerable. The main thrust of the project is to bring education to the front and center of the local public debate and involve local communities in the educational lives of their children; it supports the idea that education should not be left up to teachers and parents alone, but recognized as a community-based responsibility. The ultimate goal of FA.C.E. is that of reshaping educational policy in the territories involved. Participation thus becomes a powerful means for meeting the needs of the community and, at the same time, fosters a sense of community togetherness that may contribute to a culture of inclusion and solidarity. Collegio Carlo Alberto has been involved as an external partner in charge of impact evaluation since the program's outset.

With the exception of Teramo, a critically vulnerable area in each city was selected as the target of intervention: i) in Palermo, this was the Sperone-Brancaccio-Settecannoli district in the southern outskirts, with its high crime and school dropout rates; ii) in Reggio Emilia, it was an area on the eastern outskirts near the train station, where families of different ethnic groups have settled in recent years and integration problems have arisen; iii) in Napoli, the eastern outskirts of Ponticelli were chosen, due to its high population density, shortage of services, and high crime rate. In Teramo, the whole city is considered a potential target of intervention, since families all over the city are still dealing with the aftermath of the earthquakes of 2016 and 2017, including condemned housing and a shortage of services.

The planning partnership involves 20 institutions, including the municipalities of the cities involved, schools, and other managing bodies under the supervision of the Reggio Children Foundation (the lead partner). The point of contact in each of the four cities is the participating local school. It was deemed that reliance on a previously established program of intervention would have not been in line with the core aim of the project. Therefore, a bottom-up approach was adopted in each city, and local community groups were invited to take part in the process of planning the interventions. In 2018, planning committees were set up with the communities living in the affected areas, and families and other stakeholders involved in the educational and care services specific to early childhood were invited to take part.

\footnotetext{
${ }^{4}$ An Italian non-profit organization founded in 2016 with the aim of managing a fund established by banking foundations and the Italian government to reduce educational inequality in childhood.
} 
After a year of open debate and constructive dialogue within and between each city as well as with the leading partner, by March 2019 the final interventions had been settled upon. Parenting courses based on participatory workshops involving children and one parent each were established for the school year 2019-20 and 2020-21 in all four cities. The courses are free of charge and mainly targeted at (but not limited to) fragile families.

Over the course of 9 meetings, parents are provided with information and ideas about how to improve the learning environment at home. They learn games to play and crafts to make with their children using simple and recycled materials like paper and cardboard. The child's cognitive and soft skills are improved through sensory experience and craft activities, musical and digital workshops, and storytelling, where the relationship between child and parent is especially close and collaborative. In particular, arts and crafts stimulate imagination and creativity through the use of different materials and artistic techniques, and help build the child's self-esteem. Storytelling and music workshops tend to increase the self-confidence of the parent as they learn to engage their child in new activities. Special attention is paid to the use of digital tools in the context of learning and discovery.

The program differs slightly from city to city, but the overall content remains the same. Separate workshops are offered for children aged 0-3 and those aged 3-6. Palermo and Teramo also offer courses for parents of children under one year of age. The latter were not considered in our study, due to their age-specific content and the limited size of the cohort.

\section{Experimental design and data collection}

Once the interventions had been defined, the four cities were required to comply with a randomized controlled experiment based on a phase-in mechanism in the school year 2019-20. The parenting courses were planned to be held twice in the school year 2019-20, and families could apply to the program by the end of September 2019, although they could not decide which cycle to attend. After enrollments closed, we randomly assigned the families either to the treatment or to the control group. Due to budget constraints, 50 to 90 families were admitted per cycle ${ }^{5}$, and the remaining families were put on a waiting list in randomized order.

The treatment groups attended the course first, from October to December 2019 (to January 2020 in Teramo); the second groups attended the course from January to May 2020. The timeline of the intervention in the school year 2019-20 is illustrated in Figure 1.

\footnotetext{
${ }^{5}$ There were 50 families per cycle in Palermo and Reggio-Emilia, 60 per cycle in Teramo, and 90 per cycle in Naples.
} 
Figure 1: The timeline of the randomized controlled trial $\square$

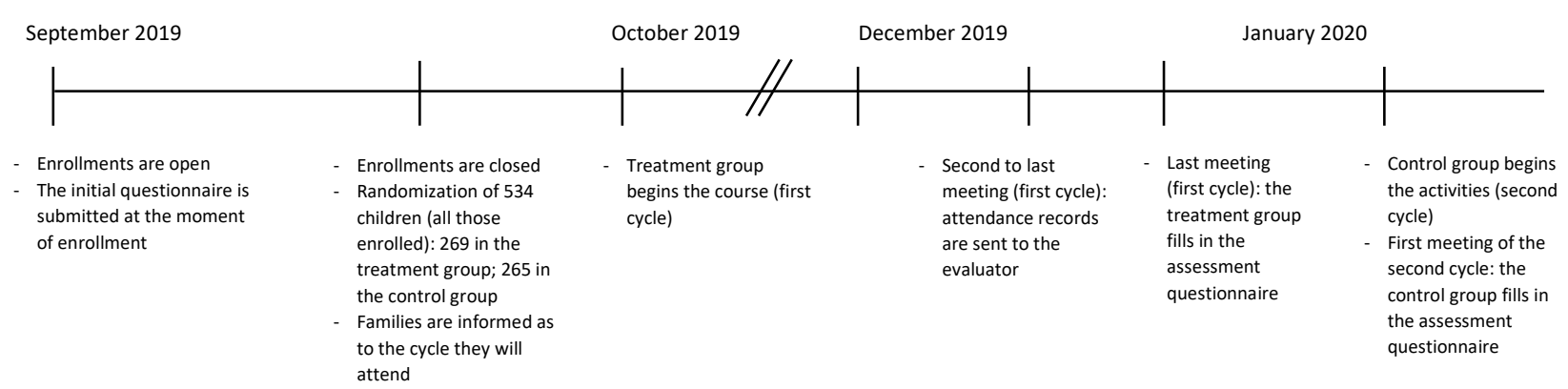

When enrolling in the program, all of the families (mostly mothers) ${ }^{6}$ answered a series of sociodemographic questions and completed a baseline questionnaire ${ }^{7}$ based on the course content. The treatment group then completed an assessment questionnaire ${ }^{8}$ at the end of the course and the same questionnaire was completed by the control group, almost at the same time, at the beginning of the course.

Both the baseline and the assessment questionnaires were organized into separate sections: i) the first concerned the use of time of parents and children together (reading, storytelling, singing, etc.), ii) the second concerned the child's use of technology and parents' opinions about it, iii) the third assessed whether parents can rely on a private network of social support. The assessment questionnaire also contained questions on parents' attitudes and beliefs about their offspring's education. In addition, the families in the treatment group provided feedback on course satisfaction.

Between the end of the first cycle and the beginning of the second cycle, we collected a total of 261 assessment questionnaires from the treatment and control groups in all four cities. The data collected from the assessment questionnaire was then used to assess the effectiveness of FA.C.E. on the outcomes of interest.

\section{Data and attrition analysis}

In September 2019, 534 children were enrolled in the FA.C.E. course. A randomization algorithm was employed $^{9}$, and 269 children to the treatment group and 265 to the control group. As shown in Table 1, the randomization was balanced according to: the gender of the youngest participating child within the family unit, the presence of siblings (and whether the information about siblings was missing), if parents were cohabiting, as well as if the mother was the participating parent.

\footnotetext{
${ }^{6}$ Among participating families, $88 \%$ of the participants were mothers $3 \%$ were both parents, and $6 \%$ were fathers.

${ }^{7}$ The baseline questionnaire and answers are provided in the Appendix.

${ }^{8}$ The assessment questionnaire is provided in the Appendix.

${ }^{9}$ If several children from the same family were enrolled in the program, they were all allocated either to the treatment or to the control group.
} 
Table 1: Comparison between treated and controlled after randomization

\begin{tabular}{|c|c|c|c|}
\hline VARIABLES & $\begin{array}{c}\text { CONTROLLED } \\
\text { Mean }\end{array}$ & $\begin{array}{c}\text { TREATED } \\
\text { Mean }\end{array}$ & $\begin{array}{c}\text { T-test } \\
\text { p-value }\end{array}$ \\
\hline Female & 0.498 & 0.435 & 0.144 \\
\hline No siblings & 0.158 & 0.175 & 0.616 \\
\hline Siblings missing ${ }^{1}$ & 0.336 & 0.279 & 0.154 \\
\hline Cohabiting parents & 0.925 & 0.937 & 0.577 \\
\hline Mother & 0.864 & 0.896 & 0.259 \\
\hline Naples & 0.249 & 0.275 & 0.495 \\
\hline Palermo & 0.196 & 0.167 & 0.387 \\
\hline Reggio Emilia & 0.260 & 0.260 & 0.997 \\
\hline Teramo & 0.294 & 0.297 & 0.938 \\
\hline
\end{tabular}

At the end of the first cycle, which overlapped with the beginning of the second cycle, we checked whether the children who had already participated (the treatment group), and those who were about to start (the control group), were statistically different from those who had decided not to attend or later dropped out. Attrition analysis showed that those who enrolled at Reggio Emilia and Naples were more likely to leave the program, or not to start the activities, but no other characteristics of the family were associated with the likelihood of leaving the program (Table 2 reports the estimated marginal effects from the logit model). Table 3 shows that once we have restricted the sample to those who remained, the treatment and control groups are still balanced in terms of gender and family characteristics. Conversely, the proportion of children across the four different municipalities varied dramatically in the control group. In particular, the proportion of children participating in Naples decreased significantly from $20.5 \%$ to $9.4 \%$.

Table 2:Attrition analysis (Logit estimation model)

\begin{tabular}{lccc}
\hline VARIABLES & $\begin{array}{c}\text { Marginal } \\
\text { Effects }\end{array}$ & $\begin{array}{c}\text { P-value } \\
\text { Lignificance } \\
\text { Level }\end{array}$ \\
\hline Female & 0.039 & 0.404 & \\
No siblings & -0.025 & 0.712 & \\
Siblings missing $^{1}$ & 0.005 & 0.920 & \\
Cohabiting parents $_{\text {Mother }}$ & -0.082 & 0.375 & \\
Reggio Emilia & -0.026 & 0.715 & \\
Naples & 0.261 & 0.000 & $* * *$ \\
Palermo & 0.375 & 0.000 & $* * *$ \\
& -0.020 & 0.771 &
\end{tabular}

Note: ${ }^{1}$ Dummy which takes value equal to 1 if the information about siblings was missing. Teramo is omitted. Significance levels $* * * 0.01, * * 0.05, * 0.1$ 
Table 3: Comparison between treatment and control group at the end of the first cycle

\begin{tabular}{lcccc}
\hline VARIABILI & $\begin{array}{c}\text { CONTROLLED } \\
\text { Mean }\end{array}$ & $\begin{array}{c}\text { TREATED } \\
\text { mean }\end{array}$ & $\begin{array}{c}\text { T-test } \\
\text { p-value }\end{array}$ & $\begin{array}{c}\text { Significance } \\
\text { Level }\end{array}$ \\
\hline Female & 0.462 & 0.402 & 0.342 & \\
No siblings & 0.154 & 0.197 & 0.375 & \\
Siblings missing ${ }^{1}$ & 0.333 & 0.273 & 0.300 & \\
Cohabiting parents & 0.940 & 0.924 & 0.621 & \\
Mother & 0.846 & 0.894 & 0.263 & \\
Reggio Emilia & 0.231 & 0.182 & 0.341 & \\
Naples & 0.094 & 0.205 & 0.015 & \\
Palermo & 0.265 & 0.235 & 0.585 & \\
Teramo & 0.410 & 0.379 & 0.614 & \\
N & 117 & 132 & & \\
\hline Note: ${ }^{1}$ Dummy which takes value equal to 1 if the information about \\
siblings was missing. Significance levels *** $0.01, * * 0.05, * 0.1$
\end{tabular}

\section{Empirical Strategy}

The empirical strategy relies on the implementation of a randomized controlled trial, where all eligible families were assigned into two groups (treatment and control group) in order to decide who was going to participate in the intervention first. The random allocation of the "treatment" (participating in the intervention first) allow us to make the treatment independent from potential outcomes, solving any problem of selection bias. Therefore, by comparing the difference in outcomes between the treatment and control groups (measured before the control group attended the course), we are able to identify the average causal effect of FA.C.E. We can express this comparison in terms of potential outcomes, with the following equation:

$$
E\left[Y_{1 i} \mid D_{i}=1\right]-E\left[Y_{0 i} \mid D_{i}=0\right]=E\left[Y_{1 i}-Y_{0 i} \mid D_{i}=1\right]
$$

where $E\left[Y_{1 i} \mid D_{i}=1\right]$ is the analyzed potential outcome of those children $i$ who attended FA.C.E. first ( $D_{i}=1$, the treatment), while $E\left[Y_{0 i} \mid D_{i}=0\right]$ is the analyzed potential outcome of those children $i$ who did not attend FA.C.E. during the first cycle. The second term $E\left[Y_{1 i}-Y_{0 i} \mid D_{i}=1\right]$ identifies the average causal effect of FA.C.E. (the effect of treatment on the treated).

As detailed in section 3, the outcomes of the children and/or of their parents, were assessed by means of a questionnaire completed by the treatment group at the end of the first cycle, and by the control group at the beginning of the second cycle.

\section{Results}

Table 4 reports the comparison of a selected set of outcomes for the treatment and control groups, most of which prove to be statistically significant. Families in the treatment group showed greater 
awareness of the importance of educational activities for the development of their offspring. At the same time, the treatment group recognized the importance of cultural sites in improving one's life. However, no difference between groups emerges from the importance attributed to the comparison with other parents on offspring's education

Table 4: Outcomes comparison between controlled and treatment group at the end of the first cycle

\begin{tabular}{|c|c|c|c|c|c|c|}
\hline \multirow[b]{2}{*}{ VARIABLES } & \multicolumn{2}{|c|}{ CONTROLLED } & \multicolumn{2}{|c|}{ TREATED } & \multirow{2}{*}{$\begin{array}{l}\text { T-test } \\
\text { p-value }\end{array}$} & \multirow{2}{*}{$\begin{array}{l}\text { Significance } \\
\text { Level }\end{array}$} \\
\hline & $\mathrm{N}$ & Mean & $\mathrm{N}$ & mean & & \\
\hline $\begin{array}{l}\text { Importance of education activities for } \\
\text { children (1 min - } 10 \text { max) }\end{array}$ & 123 & 9.236 & 135 & 9.504 & 0.005 & $* * *$ \\
\hline $\begin{array}{l}\text { Importance of cultural sites to improve } \\
\text { one's life ( } 1 \text { min - } 10 \max )\end{array}$ & 123 & 9.163 & 134 & 9.425 & 0.004 & $* * *$ \\
\hline Activity in the last week: read to the child & 120 & 0.792 & 123 & 0.870 & 0.028 & $* *$ \\
\hline $\begin{array}{l}\text { Activity in the last month: going to the } \\
\text { library, playroom }\end{array}$ & 121 & 0.397 & 117 & 0.265 & 0.054 & $*$ \\
\hline $\begin{array}{l}\text { Children use of technological devices: } \\
\text { listening of music }\end{array}$ & 92 & 0.250 & 98 & 0.337 & 0.089 & * \\
\hline $\begin{array}{l}\text { Children use of technological devices: } \\
\text { using Whatsapp }\end{array}$ & 93 & 0.0323 & 97 & 0 & 0.094 & $*$ \\
\hline Television use: Never & 121 & 0.099 & 133 & 0.150 & 0.105 & \\
\hline $\begin{array}{l}\text { Cumulative television use: Never or less } \\
\text { than } 30 \text { minutes a day }\end{array}$ & 121 & 0.264 & 133 & 0.368 & 0.03 & $* *$ \\
\hline $\begin{array}{l}\text { Cumulative other technological devices use: } \\
\text { Never }\end{array}$ & 122 & 0.336 & 133 & 0.406 & 0.148 & \\
\hline $\begin{array}{l}\text { Unsatisfaction about the time spent with the } \\
\text { child }\end{array}$ & 116 & 0.0259 & 131 & 0.0611 & 0.257 & \\
\hline $\begin{array}{l}\text { Light satisfaction about the time spent with } \\
\text { the child, s/he would like more time } \\
\text { together }\end{array}$ & 116 & 0.155 & 131 & 0.260 & 0.028 & $* *$ \\
\hline $\begin{array}{l}\text { Satisfaction about the time spent with the } \\
\text { child, s/he would like more time for } \\
\text { her/him-self }\end{array}$ & 116 & 0.362 & 131 & 0.282 & 0.129 & \\
\hline
\end{tabular}

Note: $\mathrm{N}$ stands for the number of valid answers to the question per treatment/control group. In the estimates of the p-value of the T-test, we control for Naples.

Significance levels $* * * 0.01, * * 0.05, * 0.1$

As regards the use of the time parents and children spend together, the treatment group reported spending more time reading to their children. Conversely, the control group reported more frequent visits to the library or a play group. This significant difference may be due to the fact that the treatment group was already participating in the interventions at that time, so it had less time to visit a library or a play group. No other difference appears from the frequency of other activities engaged 
in by the parent and child together, such as drawing, singing, playing outdoors or indoors, or searching on the internet for activities to do with the child. However, small sample size may influence the statical power of our estimations.

The proportion of children in the treatment group who watch television up to 30 minutes a day is higher in the treatment group. Conversely, in the control group, a higher proportion of children watch television for more than 30 minutes a day and use other digital devices than in the treatment group. However, the opinions of both groups on the use of digital devices does not differ significantly (whether it affects children’s' eyes, provides opportunities for learning, etc.).

In terms of parent satisfaction about the time they spend with their offspring, the treatment group reported feeling generally satisfied but had a higher desire to spend more time with their children than the control group. After the intervention, parents in the treatment group reported the desire to be more involved in encouraging their child's development.

\section{Conclusions}

Using randomized controlled trials to examine the effects of public policies to contrast parent and child educational poverty has been a growing area of interest in economics over the last few decades. The purpose of the present study was to assess the impact of parenting courses mainly targeting fragile families in order to raise parental awareness and to improve the amount and quality of time parents and children spend together.

This research uses data from the Italian social program FA.C.E, supported by the institution "Con $\mathrm{i}$ Bambini” and implemented in four Italian cities: Naples, Palermo, Reggio Emilia and Teramo. Its aim is to improve access to educational and care services of children aged 0-6 by promoting the participation of fragile families.

In order to perform the analysis, we use a randomized controlled trial. By comparing the answers of the questionnaires completed by the treated group at the end of the first cycle and those completed by the control group at the beginning of the second cycle, we find that attending the FA.C.E. parenting course increased the participants' awareness of the importance of educational activities for children, the frequency with which they read to their child, and their desire to spend more time with their child. Our results confirm previous studies' outcomes and contributes to the literature on the importance of programs aimed at improving parenting. 


\section{REFERENCES}

Campbell F., Conti G., Heckman J. J., Moon S. H., Pinto, R., Pungello E. and Pan Y. (2014). "Early childhood investments substantially boost adult health.” Science 343, (6178), 1478- 1485. 10.1126/science.1248429

Carneiro P.M. and Heckman J.J. (2003). “Human Capital Policy” IZA WP. 821

Daly M. (ed.) (2007), Parenting in contemporary Europe: a positive approach, Strasbourg: Council of Europe.

Daly M., Delaney L., Doyle O., Fitzpatrick N., O’ Farrelly C. “Can early intervention policies improve wellbeing? Evidence from a randomized controlled trial” WP. 201410, University College Dublin 2014

Del Boca D., Monfardini C. and Nicoletti C. (2017). "Parental and child time and cognitive development of adolescents”, Journal of Labor Economics 35(2): 565-608, April

Del Boca D. (2015). “Child care Choices and Child Outcomes”, IZA World of Labor , Number 134, March.

Del Boca D., Flinn C., and Wiswall M. (2014). "Household Choices and Child Development”, The Review of Economic Studies, Volume 81, Issue 1, January 2014, Pages 137-185.

Doepke M. and Zilibotti F. (2017). "Parenting With Style: Altruism and Paternalism in Intergenerational Preference Transmission”, Econometrica, 85: 1331-1371

Doyle O., Harmon C., Heckman J.J., Logue C., Moon S.H. (2017). "Early skill formation and the efficiency of parental investment: a randomized controlled trial of home visiting", Labour Economics 45, 40-58

Doyle O. (2020). “The First 2,000 Days and Child Skills”, Journal of Political Economy, University of Chicago Press, vol. 128(6):2067-2122.

European Union (2013). "Involving Parents in the Education of their Children". http://europa.eu/epic/practices-that-work/practice-user-registry/practices/involving- parentschildren-education_en.htm

Fiorini M. and Keane M. (2014). “How the Allocation of Children’s Time Affects Cognitive and Noncognitive Development”, Journal of Labor Economics, 32:4, 787-836

Guryan J., Hurst E. and Kearney M. (2008). "Parental education and Child Outcomes”, Journal of economic Perspectives vol 22:3

Heckman J.J. (2000). "Policies to foster human capital” Research in Economics vol 54:1, 3-56

Hsin A. (2009). "Parent's Time with Children: Does Time Matter for Children's Cognitive Achievement?” Social Indicators Research 93, 123-126

Moran P., Ghate D. and Van der Merwe A. (2004). "What works in parenting support? A review of the international evidence”, Policy Research Bureau, Research report No 574, p.129. 35

Wagner M.M., Clayton S.L. (1999). “The Parents as Teachers Program: Results from two demonstrations”, The Future of Children, 9 (1), 91-115. 10.2307/1602723 


\section{APPENDIX}

\section{BASELINE QUESTIONNAIRE}

1. Child tax code

2. Participating caregiver relationship with the child

Mother

Father

G Grandparent

$\square$ Uncle/aunt

$\square$ Cousin

$\square$ Friend

Other (please specify)

3. Are you employed at the moment?

Employed

Not employed

4. Has the child siblings?

$\square$ Yes

$\square \quad$ No

5. Who does the child spend time with, on top of parents? (other adults)

- No one else

$\begin{array}{ll}\square \text { yes } & \square \text { no } \\ \square \text { yes } & \square \text { no } \\ \square \text { yes } & \square \text { no } \\ \square \text { yes } & \square \text { no } \\ \square \text { yes } & \square \text { no }\end{array}$

- Grandparents

- Uncles/aunts

- Cousins

- Friends

6. If child spends time with other adults, is it with or without parents?
Together with parents
Even without parents

7. Does the child spend time with other children?

Several times a week

Once a week

Less than once a week

Never 
8. Do you feel self-confident in...?

- Alimentation/weaning

$\begin{array}{ll}\square \text { yes } & \square \text { no } \\ \square \text { yes } & \square \text { no } \\ \square \text { yes } & \square \text { no } \\ \square \text { yes } & \square \text { no } \\ \square \text { yes } & \square \text { no } \\ \square \text { yes } & \square \text { no } \\ \square \text { yes } & \square \text { no } \\ \square \text { yes } & \square \text { no }\end{array}$

9. In which of the listed situations, do you feel most in trouble?

- Never

- Post partum/breastfeeding

$\square$ yes $\quad \square$ no

- Alimentation/weaning

$\square$ yes $\quad \square$ no

- Organizing the day

$\square$ yes $\square$ no

- Housekeeping

$\square$ yes $\quad \square$ no

- Managing child sleep routine

$\square$ yes

$\square$ no

- Hygiene and care of the child

$\square$ yes

$\square$ yes

$\square$ yes

$\square$ no

- Child health diseases

- Communication and relationship with the child

$\square$ yes

- Playing with the child

$\square$ yes $\square$ no

10. When in trouble, do you ask for help?

Yes

No

Not much

11. Do you talk with others about your experience of parent/grandparent...?
Yes
No
Not much

12. Which is the typical day of the child?

- Attend formal childcare

$\begin{array}{ll}\square \text { yes } & \square \text { no } \\ \square \text { yes } & \square \text { no } \\ \square \text { yes } & \square \text { no } \\ \square \text { yes } & \square \text { no }\end{array}$

13. What do you do in your free time with the child?

- Stay home

- Play in the yard

$\square$ yes $\quad \square$ no

- $\quad$ Play at the park

$\square$ yes $\square$ no

- Visit relatives

$\square$ yes $\quad \square$ no

- Visit friends

$\square$ yes $\quad \square$ no

$\square$ yes

$\square$ no

- Visit friends with children

$\square$ yes

$\square$ no

- Visit local association

$\square$ yes $\square$ no 
- Go to the library/playground

$\begin{array}{ll}\square \text { yes } & \square \text { no } \\ \square \text { yes } & \square \text { no } \\ \square \text { yes } & \square \text { no }\end{array}$

14. Which are child's favorite toys/game?

- Ball

$\square$ yes $\quad \square$ no

- Building blocks

$\square$ yes $\quad \square$ no

- Various characters (superhero, dolls, animals)

$\square$ yes $\quad \square$ no

- Musical toys/instrumentals

$\square$ yes $\quad \square$ no

- Little cars

$\square$ yes $\square$ no

- Board games

$\square$ yes $\quad \square$ no

- Everyday objects

$\square$ yes $\quad \square$ no

- Not toys but playing outside

$\square$ yes $\quad \square$ no

- Not toys but watching television/videos online

$\square$ yes $\quad \square$ no

15. Do you read to your child?

Several times a week

Once a week

Less than once a week

Never

16. When you are at home, do you listen to music, sing songs/nursery rhymes with your child?

Several times a week

Once a week

Less than once a week

Never

17. Do you tell story invented by you (or from tradition) at your child?

Several times a week

Once a week

Less than once a week

Never

18. Do you do activities with your child (a drawing, building blocks, etc.)?

Several times a week

Once a week

Less than once a week

Never

19. How long does the child usually watch television a day?

$\mathrm{S} /$ he does not watch television

Up to 1 hour

Longer than an hour, less than 3 hours

Longer than 3 hours 
20. How long does the child usually watch online videos a day?

$\mathrm{S} /$ he does not watch online videos

Up to 1 hour

L Longer than an hour, less than 3 hours

$\square$ Longer than 3 hours

21. According to you, what does it mean "Well-being" for a family and a child?

- Physical health

- Psychological health and well-being

$\square$ yes $\square$ no

- Spiritual well-being

$\square$ yes $\square$ no

- Good relationship

$\square$ yes $\square$ no

- Economic security

$\square$ yes $\quad \square$ no

- Have a (good) job

$\square$ yes $\quad \square$ no

- Access to culture

- Living in an appropriate and comfortable house

- Living in an area which offers opportunities (es. services, transportations, schools, etc.)

- Living in an environmental-friendly area

$\square$ yes $\square$ no

$\square$ yes $\square$ no

$\square$ yes $\square$ no

Being well-included in the community

$\square$ yes $\quad \square$ no

$\square$ yes $\quad \square$ no

$\square$ yes $\quad \square$ no

22. Do you want to enroll your child to formal childcare in s.y. 2020/21?
Yes
No
$\checkmark$ S/he has been already enrolled in s.y. $2019 / 20$ 


\begin{tabular}{|c|c|c|c|c|c|c|c|c|c|c|}
\hline \multirow[b]{3}{*}{ VARIABLES } & \multicolumn{2}{|c|}{ All municipalities } & \multicolumn{2}{|c|}{ Naples } & \multicolumn{2}{|c|}{ Palermo } & \multicolumn{2}{|c|}{ Reggio Emilia } & \multicolumn{2}{|c|}{ Teramo } \\
\hline & (1) & (2) & (3) & (4) & $(5)$ & (6) & (7) & (8) & (9) & (10) \\
\hline & $\mathrm{N}$ & mean & $\mathrm{N}$ & mean & $\mathrm{N}$ & mean & $\mathrm{N}$ & mean & $\mathrm{N}$ & mean \\
\hline Participating caregiver: mother & 451 & 0.900 & 144 & 0.882 & 87 & 0.839 & 97 & 0.969 & 123 & 0.911 \\
\hline Expected child enrolment in formal childcare in s.y. $2020 / 21$ & 450 & 0.402 & 144 & 0.465 & 88 & 0.386 & 97 & 0.495 & 121 & 0.264 \\
\hline Child enrolment in formal childcare in s.y. 2019/20 & 450 & 0.522 & 144 & 0.465 & 88 & 0.580 & 97 & 0.371 & 121 & 0.669 \\
\hline Participating caregiver is employed & 451 & 0.488 & 144 & 0.354 & 88 & 0.295 & 97 & 0.546 & 122 & 0.738 \\
\hline Presence of siblings & 451 & 0.550 & 144 & 0.764 & 88 & 0.545 & 97 & 0.340 & 122 & 0.467 \\
\hline Child spends time only with parents, no other adult & 419 & 0.162 & 143 & 0.147 & 85 & 0.0941 & 94 & 0.298 & 97 & 0.113 \\
\hline Child spends time with grandparents, in addition to parents & 450 & 0.873 & 144 & 0.847 & 88 & 0.932 & 96 & 0.760 & 122 & 0.951 \\
\hline Child spends time with uncles/aunts, in addition to parents & 443 & 0.641 & 143 & 0.566 & 88 & 0.659 & 95 & 0.547 & 117 & 0.795 \\
\hline Child spends time with cousins (adults), in addition to parents & 436 & 0.528 & 144 & 0.528 & 88 & 0.591 & 93 & 0.441 & 111 & 0.550 \\
\hline Child spends time with friends (adults), in addition to parents & 441 & 0.612 & 143 & 0.441 & 88 & 0.580 & 93 & 0.677 & 117 & 0.795 \\
\hline Self-confident in: alimentation & 452 & 0.715 & 144 & 0.646 & 88 & 0.784 & 97 & 0.680 & 123 & 0.772 \\
\hline Self-confident in: organizing the day & 451 & 0.752 & 144 & 0.674 & 88 & 0.875 & 97 & 0.742 & 122 & 0.762 \\
\hline Self-confident in: housekeeping & 450 & 0.687 & 144 & 0.674 & 88 & 0.830 & 97 & 0.588 & 121 & 0.678 \\
\hline Self-confident in: managing child sleep routine & 451 & 0.696 & 144 & 0.667 & 88 & 0.795 & 97 & 0.608 & 122 & 0.730 \\
\hline Self-confident in: hygiene and care of the child & 452 & 0.896 & 144 & 0.806 & 88 & 0.966 & 97 & 0.897 & 123 & 0.951 \\
\hline Self-confident in: child health diseases & 450 & 0.524 & 144 & 0.549 & 88 & 0.795 & 97 & 0.320 & 121 & 0.463 \\
\hline Self-confident in: relationship with the child & 451 & 0.789 & 144 & 0.701 & 88 & 0.886 & 97 & 0.742 & 122 & 0.861 \\
\hline Self-confident in: playing with the child & 451 & 0.827 & 144 & 0.743 & 88 & 0.955 & 97 & 0.711 & 122 & 0.926 \\
\hline Difficulties reported in: nothing & 433 & 0.289 & 144 & 0.451 & 86 & 0.360 & 95 & 0.105 & 108 & 0.176 \\
\hline Difficulties reported in: postpartum/breastfeeding & 439 & 0.305 & 143 & 0.238 & 87 & 0.310 & 96 & 0.365 & 113 & 0.336 \\
\hline Difficulties reported in: alimentation & 439 & 0.223 & 143 & 0.133 & 86 & 0.198 & 97 & 0.361 & 113 & 0.239 \\
\hline Difficulties reported in: organizing the day & 436 & 0.218 & 143 & 0.168 & 85 & 0.176 & 97 & 0.237 & 111 & 0.297 \\
\hline Difficulties reported in: housekeeping & 438 & 0.251 & 143 & 0.133 & 85 & 0.188 & 97 & 0.330 & 113 & 0.381 \\
\hline Difficulties reported in: managing child sleep routine & 437 & 0.247 & 143 & 0.203 & 85 & 0.165 & 97 & 0.330 & 112 & 0.295 \\
\hline Difficulties reported in: hygiene and care of the child & 436 & 0.0573 & 143 & 0.0979 & 85 & 0.0588 & 97 & 0.0206 & 111 & 0.0360 \\
\hline Difficulties reported in: child health diseases & 440 & 0.432 & 143 & 0.273 & 86 & 0.233 & 97 & 0.619 & 114 & 0.623 \\
\hline Difficulties reported in: relationship with the child & 437 & 0.190 & 143 & 0.238 & 85 & 0.153 & 97 & 0.196 & 112 & 0.152 \\
\hline Difficulties reported in: playing with the child & 437 & 0.137 & 143 & 0.147 & 85 & 0.106 & 97 & 0.216 & 112 & 0.0804 \\
\hline Child's typical day: attend formal childcare & 447 & 0.615 & 144 & 0.569 & 87 & 0.713 & 96 & 0.375 & 120 & 0.792 \\
\hline Child's typical day: stay home & 441 & 0.565 & 143 & 0.427 & 85 & 0.753 & 97 & 0.660 & 116 & 0.517 \\
\hline Child's typical day: play in the yard & 437 & 0.412 & 143 & 0.385 & 85 & 0.353 & 96 & 0.438 & 113 & 0.469 \\
\hline Child's typical day: play at the park & 442 & 0.733 & 143 & 0.629 & 86 & 0.674 & 97 & 0.804 & 116 & 0.845 \\
\hline
\end{tabular}




\begin{tabular}{|c|c|c|c|c|c|c|c|c|c|c|}
\hline \multirow[b]{3}{*}{ VARIABLES } & \multicolumn{2}{|c|}{ All municipalities } & \multicolumn{2}{|c|}{ Naples } & \multicolumn{2}{|c|}{ Palermo } & \multicolumn{2}{|c|}{ Reggio Emilia } & \multicolumn{2}{|c|}{ Teramo } \\
\hline & (1) & (2) & (3) & (4) & $(5)$ & (6) & (7) & (8) & (9) & (10) \\
\hline & $\mathrm{N}$ & mean & $\mathrm{N}$ & mean & $\mathrm{N}$ & mean & $\mathrm{N}$ & mean & $\mathrm{N}$ & mean \\
\hline Free time (child with parent): stay home & 443 & 0.542 & 143 & 0.329 & 87 & 0.667 & 96 & 0.667 & 117 & 0.607 \\
\hline Free time (child with parent): play in the yard & 441 & 0.435 & 143 & 0.406 & 86 & 0.337 & 97 & 0.454 & 115 & 0.530 \\
\hline Free time (child with parent): play at the park & 447 & 0.823 & 143 & 0.762 & 88 & 0.818 & 97 & 0.835 & 119 & 0.891 \\
\hline Free time (child with parent): visit relatives & 445 & 0.809 & 144 & 0.764 & 87 & 0.931 & 97 & 0.732 & 117 & 0.838 \\
\hline Free time (child with parent): visit friends & 448 & 0.725 & 143 & 0.552 & 87 & 0.736 & 97 & 0.784 & 121 & 0.876 \\
\hline Free time (child with parent): visit friends with children & 448 & 0.750 & 144 & 0.632 & 87 & 0.782 & 97 & 0.784 & 120 & 0.842 \\
\hline Free time (child with parent): visit local associations & 443 & 0.244 & 143 & 0.231 & 86 & 0.233 & 97 & 0.299 & 117 & 0.222 \\
\hline Free time (child with parent): go to library/playroom & 442 & 0.278 & 143 & 0.161 & 86 & 0.186 & 97 & 0.474 & 116 & 0.328 \\
\hline Free time (child with parent): go to shopping malls & 444 & 0.628 & 143 & 0.580 & 86 & 0.907 & 97 & 0.464 & 118 & 0.619 \\
\hline Free time (child with parent): go to sports center & 444 & 0.300 & 144 & 0.236 & 86 & 0.267 & 97 & 0.299 & 117 & 0.402 \\
\hline Favourite toys/game: ball & 447 & 0.720 & 143 & 0.685 & 87 & 0.816 & 97 & 0.691 & 120 & 0.717 \\
\hline Favourite toys/game: building blocks & 445 & 0.676 & 143 & 0.601 & 87 & 0.782 & 96 & 0.583 & 119 & 0.765 \\
\hline Favourite toys/game: various characters & 447 & 0.685 & 144 & 0.722 & 87 & 0.862 & 97 & 0.454 & 119 & 0.697 \\
\hline Favourite toys/game: musical instruments & 445 & 0.708 & 143 & 0.510 & 87 & 0.724 & 97 & 0.825 & 118 & 0.839 \\
\hline Favourite toys/game: little cars & 445 & 0.528 & 143 & 0.413 & 88 & 0.727 & 97 & 0.423 & 117 & 0.607 \\
\hline Favourite toys/game: board games & 443 & 0.433 & 144 & 0.403 & 86 & 0.558 & 97 & 0.258 & 116 & 0.526 \\
\hline Favourite toys/game: everyday objects & 447 & 0.676 & 144 & 0.431 & 87 & 0.770 & 97 & 0.742 & 119 & 0.849 \\
\hline Favourite toys/game: play outside & 444 & 0.662 & 143 & 0.420 & 86 & 0.860 & 97 & 0.670 & 118 & 0.805 \\
\hline Favourite toys/game: watching television & 442 & 0.475 & 144 & 0.417 & 86 & 0.779 & 97 & 0.237 & 115 & 0.522 \\
\hline Well-being is: physical health & 446 & 0.937 & 144 & 0.854 & 88 & 0.989 & 97 & 0.969 & 117 & 0.974 \\
\hline Well-being is: psychological well-being & 448 & 0.975 & 144 & 0.958 & 88 & 0.989 & 97 & 0.959 & 119 & 1 \\
\hline Well-being is: spiritual well-being & 443 & 0.797 & 144 & 0.694 & 86 & 0.953 & 97 & 0.763 & 116 & 0.836 \\
\hline Well-being is: good relationships & 446 & 0.913 & 143 & 0.846 & 86 & 0.977 & 97 & 0.907 & 120 & 0.950 \\
\hline Well-being: economic security & 443 & 0.797 & 143 & 0.692 & 86 & 0.860 & 97 & 0.814 & 117 & 0.863 \\
\hline Well-being is: having a job & 445 & 0.789 & 144 & 0.674 & 87 & 0.943 & 97 & 0.814 & 117 & 0.795 \\
\hline Well-being is: access to culture & 444 & 0.865 & 144 & 0.722 & 86 & 0.907 & 97 & 0.918 & 117 & 0.966 \\
\hline Well-being is: appropriate and comfortable house & 444 & 0.883 & 144 & 0.792 & 86 & 0.977 & 97 & 0.928 & 117 & 0.889 \\
\hline Well-being is: living in an area which offers opportunities & 444 & 0.813 & 144 & 0.833 & 86 & 0.907 & 97 & 0.763 & 117 & 0.761 \\
\hline Well-being is: environment-friendly area & 442 & 0.778 & 143 & 0.629 & 86 & 0.895 & 97 & 0.825 & 116 & 0.836 \\
\hline Well-being is: being well integrated in the community & 444 & 0.831 & 144 & 0.757 & 86 & 0.953 & 97 & 0.773 & 117 & 0.880 \\
\hline If child spends time with other adults, it is also without parents & 438 & 0.694 & 144 & 0.625 & 87 & 0.759 & 87 & 0.598 & 120 & 0.800 \\
\hline $\begin{array}{l}\text { If child spends time with other adults, it is only together with } \\
\text { parents }\end{array}$ & 438 & 0.306 & 144 & 0.375 & 87 & 0.241 & 87 & 0.402 & 120 & 0.200 \\
\hline
\end{tabular}




\begin{tabular}{|c|c|c|c|c|c|c|c|c|c|c|}
\hline \multirow[b]{2}{*}{ VARIABLES } & \multicolumn{2}{|c|}{ All municipalities } & \multicolumn{2}{|c|}{ Naples } & \multicolumn{2}{|c|}{ Palermo } & \multicolumn{2}{|c|}{ Reggio Emilia } & \multicolumn{2}{|c|}{ Teramo } \\
\hline & $\begin{array}{l}(1) \\
\mathrm{N} \\
\end{array}$ & $\begin{array}{c}(2) \\
\text { mean }\end{array}$ & $\begin{array}{l}\text { (3) } \\
\mathrm{N}\end{array}$ & $\begin{array}{c}(4) \\
\text { mean }\end{array}$ & $\begin{array}{l}(5) \\
\mathrm{N}\end{array}$ & $\begin{array}{c}(6) \\
\text { mean }\end{array}$ & $\begin{array}{l}(7) \\
\mathrm{N}\end{array}$ & $\begin{array}{c}(8) \\
\text { mean }\end{array}$ & $\begin{array}{l}(9) \\
\mathrm{N} \\
\end{array}$ & $\begin{array}{c}(10) \\
\text { mean }\end{array}$ \\
\hline When in trouble, I ask for help: no & 452 & 0.117 & 144 & 0.194 & 88 & 0.205 & 97 & 0.0412 & 123 & 0.0244 \\
\hline When in trouble, I ask for help: not much & 452 & 0.290 & 144 & 0.326 & 88 & 0.216 & 97 & 0.268 & 123 & 0.317 \\
\hline When in trouble, I ask for help: yes & 452 & 0.593 & 144 & 0.479 & 88 & 0.580 & 97 & 0.691 & 123 & 0.659 \\
\hline I talk with others of my experience as parent: no & 452 & 0.0686 & 144 & 0.111 & 88 & 0.136 & 97 & 0.0103 & 123 & 0.0163 \\
\hline I talk with others of my experience as parent: not much & 452 & 0.137 & 144 & 0.194 & 88 & 0.125 & 97 & 0.0825 & 123 & 0.122 \\
\hline I talk with others of my experience as parent: yes & 452 & 0.794 & 144 & 0.694 & 88 & 0.739 & 97 & 0.907 & 123 & 0.862 \\
\hline When in troubles, I ask for help: no, or not much & 452 & 0.407 & 144 & 0.521 & 88 & 0.420 & 97 & 0.309 & 123 & 0.341 \\
\hline I talk with others of my experience as parent: no, or not much & 452 & 0.206 & 144 & 0.306 & 88 & 0.261 & 97 & 0.0928 & 123 & 0.138 \\
\hline Time spent with other children: never & 451 & 0.0488 & 144 & 0.0486 & 88 & 0 & 97 & 0.113 & 122 & 0.0328 \\
\hline Time spent with other children: less than once a week & 451 & 0.109 & 144 & 0.0764 & 88 & 0.114 & 97 & 0.165 & 122 & 0.0984 \\
\hline Time spent with other children: once a week & 451 & 0.133 & 144 & 0.0972 & 88 & 0.227 & 97 & 0.155 & 122 & 0.0902 \\
\hline Time spent with other children: several times a week & 451 & 0.710 & 144 & 0.778 & 88 & 0.659 & 97 & 0.567 & 122 & 0.779 \\
\hline Time spent with other children: never or less than once a week & 451 & 0.157 & 144 & 0.125 & 88 & 0.114 & 97 & 0.278 & 122 & 0.131 \\
\hline Time spent with other children: never or up to once a week & 451 & 0.290 & 144 & 0.222 & 88 & 0.341 & 97 & 0.433 & 122 & 0.221 \\
\hline Reading to the child: never & 450 & 0.156 & 143 & 0.266 & 88 & 0.227 & 97 & 0.0722 & 122 & 0.0410 \\
\hline Reading to the child: less than once a week & 450 & 0.176 & 143 & 0.154 & 88 & 0.295 & 97 & 0.165 & 122 & 0.123 \\
\hline Reading to the child: once a week & 450 & 0.164 & 143 & 0.259 & 88 & 0.193 & 97 & 0.0619 & 122 & 0.115 \\
\hline Reading to the child: several times a week & 450 & 0.504 & 143 & 0.322 & 88 & 0.284 & 97 & 0.701 & 122 & 0.721 \\
\hline Reading to the child: never or less than once a week & 450 & 0.331 & 143 & 0.420 & 88 & 0.523 & 97 & 0.237 & 122 & 0.164 \\
\hline Reading to the child: never or up to once a week & 450 & 0.496 & 143 & 0.678 & 88 & 0.716 & 97 & 0.299 & 122 & 0.279 \\
\hline Singing to the child: never & 452 & 0.0243 & 144 & 0.0486 & 88 & 0.0114 & 97 & 0.0309 & 123 & 0 \\
\hline Singing to the child: less than once a week & 452 & 0.0642 & 144 & 0.0625 & 88 & 0.114 & 97 & 0.0619 & 123 & 0.0325 \\
\hline Singing to the child: once a week & 452 & 0.0774 & 144 & 0.0972 & 88 & 0.125 & 97 & 0.0619 & 123 & 0.0325 \\
\hline Singing to the child: several times a week & 452 & 0.834 & 144 & 0.792 & 88 & 0.750 & 97 & 0.845 & 123 & 0.935 \\
\hline Singing to the child: never or less than once a week & 452 & 0.0885 & 144 & 0.111 & 88 & 0.125 & 97 & 0.0928 & 123 & 0.0325 \\
\hline Singing to the child: never or up to once a week & 452 & 0.166 & 144 & 0.208 & 88 & 0.250 & 97 & 0.155 & 123 & 0.0650 \\
\hline Storytelling: never & 451 & 0.146 & 143 & 0.105 & 88 & 0.284 & 97 & 0.175 & 123 & 0.0732 \\
\hline Storytelling: less than once a week & 451 & 0.175 & 143 & 0.196 & 88 & 0.182 & 97 & 0.155 & 123 & 0.163 \\
\hline Storytelling: once a week & 451 & 0.171 & 143 & 0.175 & 88 & 0.182 & 97 & 0.175 & 123 & 0.154 \\
\hline Storytelling: several times a week & 451 & 0.508 & 143 & 0.524 & 88 & 0.352 & 97 & 0.495 & 123 & 0.610 \\
\hline Storytelling: never or less than once a week & 451 & 0.322 & 143 & 0.301 & 88 & 0.466 & 97 & 0.330 & 123 & 0.236 \\
\hline Storytelling: never or up to once a week & 451 & 0.492 & 143 & 0.476 & 88 & 0.648 & 97 & 0.505 & 123 & 0.390 \\
\hline
\end{tabular}




\begin{tabular}{|c|c|c|c|c|c|c|c|c|c|c|}
\hline \multirow[b]{2}{*}{ VARIABLES } & \multicolumn{2}{|c|}{ All municipalities } & \multicolumn{2}{|c|}{ Naples } & \multicolumn{2}{|c|}{ Palermo } & \multicolumn{2}{|c|}{ Reggio Emilia } & \multicolumn{2}{|c|}{ Teramo } \\
\hline & $\begin{array}{l}(1) \\
N\end{array}$ & $\begin{array}{l}(2) \\
\text { mean }\end{array}$ & $\begin{array}{l}(3) \\
N\end{array}$ & $\begin{array}{l}(4) \\
\text { mean }\end{array}$ & (5) & $\begin{array}{c}(6) \\
\text { mean }\end{array}$ & (7) & $\begin{array}{c}(8) \\
\text { mean }\end{array}$ & $\begin{array}{l}(9) \\
\mathrm{N}\end{array}$ & $\begin{array}{c}(10) \\
\text { mean }\end{array}$ \\
\hline $\begin{array}{l}\text { Activities together with the child (drawing, building blocks, etc): } \\
\text { never }\end{array}$ & 452 & 0.0664 & 144 & 0.0278 & 88 & 0.0341 & 97 & 0.175 & 123 & 0.0488 \\
\hline $\begin{array}{l}\text { Activities together with the child (drawing, building blocks, etc): } \\
\text { less than once a week }\end{array}$ & 452 & 0.0642 & 144 & 0.0417 & 88 & 0.114 & 97 & 0.0928 & 123 & 0.0325 \\
\hline $\begin{array}{l}\text { Activities together with the child (drawing, building blocks, etc): } \\
\text { once a week }\end{array}$ & 452 & 0.128 & 144 & 0.236 & 88 & 0.125 & 97 & 0.0515 & 123 & 0.0650 \\
\hline $\begin{array}{l}\text { Activities together with the child (drawing, building blocks, etc): } \\
\text { several times a week }\end{array}$ & 452 & 0.741 & 144 & 0.694 & 88 & 0.727 & 97 & 0.680 & 123 & 0.854 \\
\hline $\begin{array}{l}\text { Activities together with the child (drawing, building blocks, etc): } \\
\text { never or less than once a week }\end{array}$ & 452 & 0.131 & 144 & 0.0694 & 88 & 0.148 & 97 & 0.268 & 123 & 0.0813 \\
\hline $\begin{array}{l}\text { Activities together with the child (drawing, building blocks, etc): } \\
\text { never or up to once a week }\end{array}$ & 452 & 0.259 & 144 & 0.306 & 88 & 0.273 & 97 & 0.320 & 123 & 0.146 \\
\hline Watching television: never & 342 & 0 & 127 & 0 & 76 & 0 & 44 & 0 & 95 & 0 \\
\hline Watching television: never or up to 1 hour & 342 & 0.424 & 127 & 0.323 & 76 & 0.474 & 44 & 0.614 & 95 & 0.432 \\
\hline Watching television: never or up to 3 hours & 342 & 0.921 & 127 & 0.898 & 76 & 0.908 & 44 & 0.932 & 95 & 0.958 \\
\hline Watching videos online: never & 286 & 0 & 114 & 0 & 73 & 0 & 27 & 0 & 72 & 0 \\
\hline Watching videos online: never or up to 1 hour & 286 & 0.640 & 114 & 0.447 & 73 & 0.589 & 27 & 0.741 & 72 & 0.958 \\
\hline Watching videos online: never or up to 3 hours & 286 & 0.916 & 114 & 0.868 & 73 & 0.890 & 27 & 0.963 & 72 & 1 \\
\hline
\end{tabular}


1. Child tax code

2. Participating caregiver relationship with the child
Mother
Father
Grandparent
Uncle/aunt
Cousin
Friend
Babysitter

Other (please specify)

3. Are you employed at the moment?
Yes, part-time
Yes, full-time
No

4. In last week, apart from FACE course, have you ... ?

- Made a drawing with the child

$\begin{array}{ll}\square \text { yes } & \square \text { no } \\ \square \text { yes } & \square \text { no } \\ \square \text { yes } & \square \text { no } \\ \square \text { yes } & \square \text { no } \\ \square \text { yes } & \square \text { no } \\ \square \text { yes } & \square \text { no } \\ \square \text { yes } & \square \text { no } \\ & \square \text { yes } \quad \square \text { no }\end{array}$

5. In the last month, apart from FACE course, have you ... ?

- Been to a movie theatre with the child

- Participated to a workshop at the museum/local association

- Visited a library/playground

- Attended a public event together with the child (e.g. children's choir)

$\square$ yes

- Organized a lunch/dinner with other families

- Talk with other adults about children's education

- Visited local associations/groups with the child

- Visited worship with the child 
6. Are you satisfied with the time you spend with your child?

(please tick the answer that best describes how you feel)

$\square$ I am happy that we spend (almost) the whole day together, but I would like to have more time to play with him / her than to take care of daily tasks and family in general

] I'm sorry that I do not see him / her for many hours during the day (either because $\mathrm{s} / \mathrm{h}$ is in kindergarten or due to my work commitments, etc.), but I am happy to be able to find some minutes to play with him / her at the end of the day

$\square$ I am not happy: I have little free time in general, and I cannot use it as I would like with my child

I am happy with the time I spend with him / her and how we use it

7. On a scale of 1 (not confident at all) to 10 (completely confident), indicate how confident you feel in the following situations/topics.

Alimentation

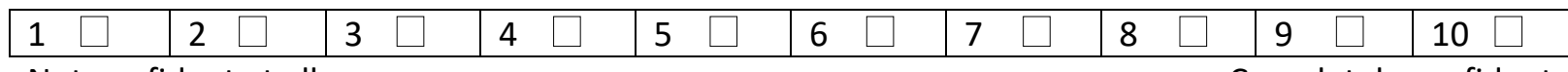

Not confident at all Completely confident

Organizing the day

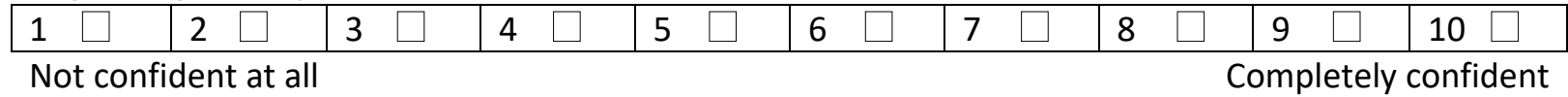

In the communication and the relationship with the child

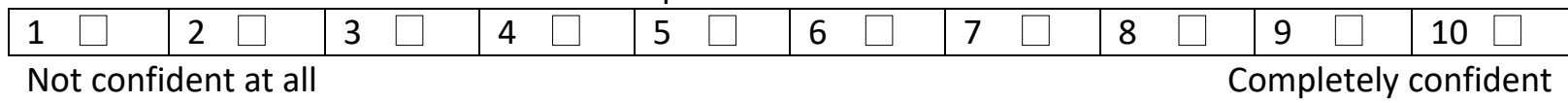

In playing with the child

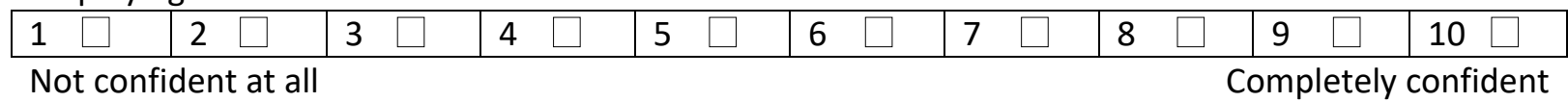

In sharing with other parents/adults

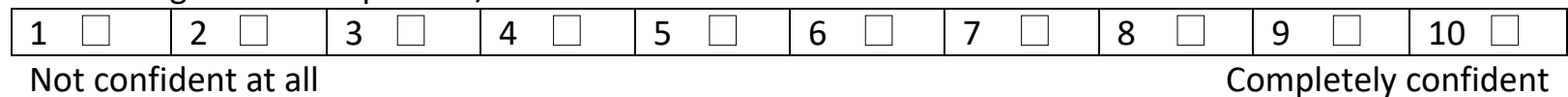

8. How long does the child usually watch television a day?

$\mathrm{S} /$ he does not watch television

- Less than $\mathbf{3 0}$ minutes

Longer than 30 minutes, less than 1 hour

$\square \quad$ Longer than 1 hour

9. How long does the child usually watch online videos a day?

$\mathrm{S} /$ he does not watch television

Less than 30 minutes

Longer than 30 minutes, less than 1 hour

Longer than 1 hour 
10. If the child uses either a tablet or a mobile phone, for what purposes?

(please tick at most TWO answers)

Watch videos on youtube

Play games

See/take pictures

Listen to music

Use whatsapp

Other

11. Beyond time, what do you think about using:

\section{Television}

(mark all the answers you agree with)

It calms the child when $\mathrm{s} / \mathrm{he}$ is nervous

It gives the parent, or other adult, the opportunity to complete a task

It hurts the child (sight, makes her/him nervous, etc.)

It is possible to learn new stuff

\section{Tablet}

(mark all the answers you agree with)

It calms the child when $\mathrm{s} /$ he is nervous

It gives the parent, or other adult, the opportunity to complete a task

It hurts the child (sight, makes her/him nervous, etc.)

It is possible to learn new stuff

\section{Mobile phone}

(mark all the answers you agree with)

It calms the child when s/he is nervous

It gives the parent, or other adult, the opportunity to complete a task

It hurts the child (sight, makes her/him nervous, etc.)

It is possible to learn new stuff

12. On a scale of 1 to 10 , where 1 indicates "not at all" and 10 "very much", how important do you think it is to talk/discuss with other parents / adults to deal with the child's development / educational path?

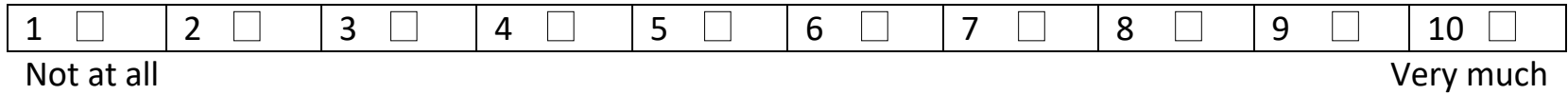

13. On a scale of 1 to 10 , where 1 indicates "not at all" and 10 "very much", how important do you think it is to participate in children educational activities to deal with child's development / educational path?

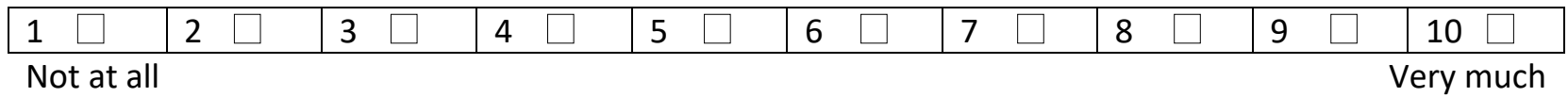


14. On a scale of 1 to 10 , where 1 indicates "not at all" and 10 "very much", how important do you think are cultural places for education to improve people's life?

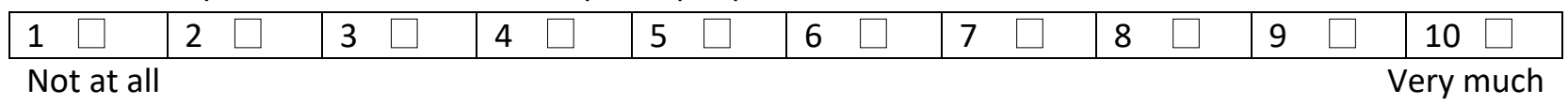

\section{COURSE'S SATISFACTORY QUESTIONS}

15. In which aspects of daily life do you think FA.C.E. course has been useful?

Relationship with the child

Alimentation

Organizing the day

Playing with the child

$\square$ Other

16. On a scale of 1 to 10 , where 1 indicates "not at all" and 10 "very much", how much did you like the course attended?

\begin{tabular}{|c|c|c|c|c|c|c|c|c|c|c|c|c|c|c|c|c|c|}
\hline $1 \square$ & 2 & $\square$ & 3 & $\square$ & 4 & $\square$ & 5 & $\square$ & 6 & $\square$ & 7 & $\square$ & 8 & $\square$ & 9 & $\square$ & 10 \\
\hline
\end{tabular}

